\title{
Sending in die nabloei van die Marxisme-Leninisme
}

P Verster

(UOVS)

\section{ABSTRACT}

"Mission in the aftermath of Marxism-Leninism"

Marxism-Leninism as ideology suffered severe setbacks. The question is in which way mission can still be relevant in the aftermath of this prominent ideology. The idea of freedom as essential part of Western philosophy is discussed in relation with Marxism/Leninism. The inftuence of Perestroika and the effect it had on the ideology is also discussed. In the end mission must still be relevant. Certain problems with evangelical missionary efforts in Russia en Cuba are mentioned. The church should, however, remain relevant in the sense of dealing with man's essential relation to freedom in the kingdom of God.

\section{INLEIDING}

Die ideologie Marxisme-Leninisme het die afgelope dekade ernstige terugslae ervaar. Waar dit ongeveer tien jaar gelede nog 'n hoogbloei beleef het, is dit nou nie meer die geval nie. Die algemene oortuiging was dat dit wyer as ideologie aanvaar sou word. Dit is nou duidelik dat daar, wat die ideologie betref, ernstige vrae gevra word. Daar kan beweer word dat die ideologie as sodanig geweldig gediskrediteer is. Daar is nog enkele gebiede oor waar dit as ideologie nagevolg word, byvoorbeeld China, Kuba en Noord-Korea. Die kern van die Marxisme-Leninisme word egter ernstig bevraagteken.

\section{NAVORSINGSPROBLEEM EN HIPOTESE}

In hierdie artikel word enkele aspekte van die Marxisme-Leninisme ontleed ten opsigte van die Westerse vryheidsideaal in die lig van die ommeswaai wat gekom het. Die nuwe situasie wat tot stand gekom het, word ontleed. Die vraag wat dan uiteindelik aan die orde gestel sal word is hoe sending binne hierdie nuwe situasie en met inagneming van die vryheidsideaal steeds sinvol bedryf kan word. As hipotese word gestel dat die kerk in ekumeniese verband opnuut na die vryheid van die mens moet vra om ook 
dié vryheid gestalte te gee in die gemeenskap waar God se koninkryk sigbaar word.

\section{MARXISME-LENINISME EN VRYHEID}

\subsection{Marx en vryheid}

Marxisme-Leninisme het as basiese uitgangspunt die mens in sy situasie. Marx is aangegryp deur die nood van die mens. Sy Das Kapital is eintlik 'n ernstige besinning oor hoe die mens vry kan kom van die onderdrukkende omstandighede van die privaat produksie waaronder hy of sy geplaas word.

"Let us now picture to ourselves, by way of change, a community of free individuals, carrying on their work with the means of production in common, in which the labour-power of all the different individuals is consciously applied as the combined labour-power of the community. All the characteristics of Robinson's labour are here repeated, but with this difference, that they are social, instead of individual. Everything produced by him was exclusively the result of his own personal labour, and therefore simply an object of use for himself. The total product of our community is a social product. One portion serves as fresh means of production and remains social" 2 .

Die vryheidsideaal bestaan ook by Marx. Hy neem dit oor van Rousseau en uiteindelik Hegel. Die vryheidsideaal wat so inherent aan die Westerse beskawing is, kom ook by die Marxisme-Leninisme sentraal voor. Die vryheidsideaal bevestig dat die mens nie in 'n situasie geplaas moet word waar hy vervreemd van homself moet bestaan nie. Alhoewel die Marxisme-Leninisme wesenlik God se bestaan en invloed misken en ook ontken dat die mens 'n ewige bestemming by God het, wil dit tog die mens as sodanig vrymaak om tot homself te kom. Die vervreemde mens, vervreem van sy arbeid, vervreem van sy bestaan, moet daartoe gebring word om weer in ' $n$ bevrydende verhouding tot homself te $\mathrm{kom}^{3}$. Dit is juis die kapitalisme wat die verhouding van mens tot arbeid versteur. Die hantering van surpluswaarde is in dié verband betekenisvol ${ }^{4}$. Vir Marx ${ }^{5}$ is die moderne masjinerie van sy tyd voorbeeld van vervreemding van arbeid en daarmee saam van vryheid: "By means of its conversion into an automaton, the instrument of labour confronts the labourer, during the labour-process, in the shape of capital, of dead labour, that dominates and pumps dry, living labour power. The separation of the intellectual powers of production from the manual labour, and the conversion of those powers into the might of capital over labour, as we have already shown, finally 
completed by modern industry erected on the foundation of the machinery".

Kolakowski ${ }^{6}$ se belangwekkende boek Main currents of Marxism behandel die aspekte volledig: "Marx was certain that the proletariat as the collective Prometheus would, in the universal revolution, sweep away the age-long contradiction between the interest of the individual and that of species. In this way, too, capitalism was the harbinger of socialism. By smashing the power of tradition, brutally rousing nations from their slumbers, revolutionising production, and liberating fresh human sources, capitalism has made a civilization in which man for the first time was able to show what he could do, although as yet his prowess took non-human and anti-human forms. It was pitifully sentimental to upbraid capitalism in hope of stopping or diverting its victorious advance. The conquest of nature must go forward: in the next stage, men would achieve mastery over the social conditions of progress" 7 .

Die vraag aan die orde is of Marx ooit werklik in staat sou wees om die nuwe hoop vir mense te skep. Kolakowski ${ }^{8}$ toon aan dat Marx se oortuiging dat die proleriaat uiteindelik sou seëvier en die nuwe gemeenskap tot stand sou bring, nie berus het op wetenskaplike ondersoek nie, maar op die oortuiging van 'n profeet wat 'n argument bou op sy interpretasie van die werklikheid. Seigel ${ }^{9}$ meen dat Marx nie daarin kon slaag om vry te kom van persoonlike lewe en die toepassing van sy teorie in die werlikheid nie, sodat hy eintlik aan die einde ontgogel moet staan voor die onvermoë van die teorie om sy ideaal te verwesenlik. "The tension between a theoretical structure which, although the sole source of scientific comprehension, could be easily mistaken for the empty dialectical play of abstract idealism, and an empirical world which, although uniquely real, was illusory and irrational, led Marx to impasses he could not circumvent". Marx kon ook nie die noodwendigheid waarop sy teorie gebou is, laat geld sonder om daarmee ook die mens self as middelaar in die sentrum te plaas nie ${ }^{10}$.

\section{Ontwikkeling van die vryheidsideaal}

Duvenhage ${ }^{11}$ toon aan dat die vryheidsideaal ook deur die sogenaamde Frankfurter Schule geïnterpreteer word in Marxistiese raam. Die Verligting kon nie self die oplossing vir die vervreemding van die mens bied nie. Die gevolg was dat die Marxistiese kritiek op die kapitalisme juis was, maar ook weer in die put van vervreemding vasval - vandaar die verval van kommunisme in Rusland. Kilminster ${ }^{12}$ bevestig dat die utopie nie meer noodwendig volg op die verwagte ineenstorting van kapitalisme 
nie, en dat die Marxistiese teorie juis daarom onder verdenking kom. Carter ${ }^{13}$ toon aan dat Marx juis meen dat die teenstrydighede deur arbeid oorkom kan word: "In other words, it is by interacting with the world through labour, by transforming the world to their benefit and, in the process, by transforming themselves that human beings come to have knowledge of the world. Labour is thus offered as the solution to the epistemological problems associated with the reflection theory".

\section{Negatiewe gevolge van die Marxisties-Leninistiese vryheidsideaal}

Die ironie is egter dat waar hierdie vryheidsideal vir die MarxismeLeninisme so belangrik was, die teenoorgestelde gegeld het waar die ideologie die heersende ideologie was. Juis daarom is Marx se godsdienskritiek van die uiterste belang. Kommunisme ${ }^{14}$ sou godsdiens totaal oorbodig maak: "But Marx would deny that, in parallel, the institutional/ oppressive side of religion might disappear but its functions continue. In his earlier writings, which looked on religion as opium, the reason for this was that communism, being a self-creating society with fully satisfying interpersonal relationships, has no need for religion with its themes of creation, dependency and mediation". In die belangrike boek Discretion and Valour ${ }^{15}$ word duidelik aangetoon hoedat daar vir die Christen onder die Marxisties-Leninistiese state 'n ongelooflike dilemma geskep is. Hulle moes of diskressie gebruik en dan kompromitteer, of hulle moes met daadkrag getuig en dan onderdrukking tegemoetgaan, of in ' $n$ ondergrondse kerk hulleself organiseer.

Vir die Christen het die Marxisme-Leninisme ellende beteken, asook die allerverskriklikste verdrukking. Michael Bordeaux ${ }^{16}$, skets in sy bekende boek Opium of the People baie duidelik hoedat die ortodokse kerk in 'n greep vasgevang is deur die Marxisme-Leninisme in die Sowjetunie.

Waartoe het dit gelei? Dit het daartoe gelei dat die kerk verstar het en, alhoewel hy probeer het om te getuig in die Sowjetunie, gesukkel het om universeel kerk te wees. Die kerk kon net nie meer vrykom om te getuig soos wat die getuienis aangaande Jesus Christus van die kerk sou vereis nie. Kompromittering was noodsaaklik, en daarom was dit ook noodsaaklik dat in baie opsigte die kerk uiteindelik die MarxismeLeninisme moes aanvaar en moes verdedig.

By buitelandse kongresse het ortodokse kerkleiers dikwels sterk na vore gekom om die optrede van die Sowjetunie te verdedig. Die vraag is inderdaad ook gestel of die kerk enigsins onder sulke omstandighede kon bestaan. Daarteenoor het die gedagte ontstaan dat die kerk net as ondergrondse kerk kon bestaan, dit wil sê die kerk het homself gesien as 'n kerk 
onder die kruis. Veral sendinggenootskappe in Westerse lande het gepoog om hierdie bestaan van die kerk te bevorder. Die enigste ware kerk sou die ondergrondse kerk wees. Pastoor Wurmbrand, Broer Andrew, pastoor Joe Bass en andere het hulle daarop toegelê om in die Westerse wêreld te verkondig dat daar 'n ondergrondse kerk bestaan en dat daardie kerk onder groot druk verkeer.

Maar hierdie kerk het te doen gehad met die vryheidsideaal. Dit het te doen gehad met die mens onder die Marxisme-Leninisme waar die vryheidsideaal nog geleef het. Omdat die Marxisme-Leninisme nie kon lei tot die vryheid van die mens nie, omdat dit die mens verkneg het, het daar 'n nuwe soeke ontstaan. En die vraag wat natuurlik toe na vore gekom het, was hoe die Marxisme-Leninisme verstaan moes word.

Aanvanklik is gemeen dat die onderdrukkende omstandighede verwerk moes word. Daar is verstaan dat onder die onderdrukkende omstandighede die kerk vir homself 'n plek moes vind. Persone soos Helmut Gollwitzer ${ }^{17}$ en ook Jan Millich Lochman ${ }^{18}$ het vanuit Westerse posisies probeer om die Christelike boodskap en die Marxisme-Leninisme met mekaar te verbind. Dit is nie vreemd nie dat ook vanuit die bevrydingsteologie sterk aansluiting gevind is by die Marxisme-Leninisme omdat daardeur gemeen is dat die vryheidsideaal weer na vore sou kom. Die vryheidsideaal is inherent aan die Westerse beskawing en kan daardeur gedien word. Dit was die saak wat na vore gebring is.

Marx en Lenin wat die Marxisme toegepas het, het daar egter iets heel anders onder verstaan as wat in die Westerse beskawing na vore gebring is. Daarom het die vryheidsideaal onder die Marxisme-Leninisme 'n kleur begin kry van die allerverskriklikste onderdrukking. Die mens se vryheid was gekoppel aan sy bestaan in die Marxisme-Leninisme; sy vryheid is ingeperk om hom juis so volgens hulle beskouing vry te maak. As mens moes hy dus geweldig baie prysgee. Hy is ingebind in 'n situasie waar hy net eenvoudig homself moes prysgee en sy vryheid moes agterlaat om deel te word van die gemeenskap waaronder hy geleef het. Dit is dan nie vreemd nie dat skrywers soos Solzjenitsin en andere moes aantoon tot watter uiterstes die Marxisme-Leninisme sou gaan.

'n Verligte werk het in Suid-Afrika verskyn onder die titel Christen, Kommunis en Sosialis in die Nuwe Suid-Afrika ${ }^{19}$ deur Deon Rossouw. Dit is verbasend dat so 'n positiewe blik op die Marxisme-Leninisme reeds daardie tyd kon voorkom. Rossouw ${ }^{20}$ skryf: "Die feit dat die kommunisme en die christelike geloof reeds nou al gemaklik saambestaan in veral die Swart gemeenskap, open nou al vrugbare moontlikhede vir samewerking tussen Christene en Kommuniste. Vir sover as wat Christene die geleent- 
heid het om betrokke te raak op gebiede waar die Kommuniste ook betrokke is, bied dit vir Christene die geleentheid om in sulke situasies 'n christelike stempel af te druk". Dit is 'n aanduiding van 'n totale misverstaan van die basiese sake wat aan die wortel van hierdie ideologie lê asook 'n misverstaan van Perestroika se invloed. Die ideologie het nie sy inherente vyandigheid teen die koninkryk van God prysgegee nie, maar Perestroika was reeds 'n wegbeweeg van die ideologiese basis en lê dus 'n nuwe grondslag.

\subsection{Die ontwikkeling van Perestroika}

Hierdie ideologie is egter ernstig geskud, juis omdat die vryheidsideaal weer na vore getree het. Gorbachev kon eintlik nie langer die vryheidsideaal in Oos-Europa, veral in Oos-Duitsland, Pole en Hongarye keer nie. Daarom is dit so aangrypend dat hy in Perestroika die volgende skryf:

"Perestroika means priority development of the social sphere aimed at even better satisfaction of the Soviet people's requirements for good living and working conditions, for good rest and recreation, education and health care. It means unceasing concern for cultural and spiritual wealth, for the culture of every individual and society as a whole".

"Perestroika means the elimination from society of the distortions of social ethics, the consistent implementation of the principles of social justice. It means the unity of words and deeds, rights and duties. It is the elevation of honest, highly-qualified labour, the overcoming of levelling tendencies in pay and consumerism".

"I stress once again: perestroika is not some kind of illumination or revelation. To restructure our life means to understand the objective necessity for renovation and acceleration. And that necessity emerged in the heart of our society. The essence of perestroika lies in the fact that it unites socialism with democracy and revives the Leninist concept of social construction both in theory and in practice. Such is the essence of perestroika, which accounts for its genuine revolutionary spirit and its all embracing scope ${ }^{21}$.

Perestroika het op internasionale gebied vernuwing gebring, veral op die vlak van die internasionale reg, met inbegrip daarin van mense se nuwe verhouding tot mekaar. Die vryheid van die mens is bevestig op heel ander wyse as by Marx 22 .

Dit was 'n al sterker wordende en al groter groeiende oortuiging wat by mense gekom het: die vryheid moet gesoek word; die vryheid moet gevind word; die vryheid moet kom. En daardie vryheid, die vryheidsideaal van die Westerse beskawing, het weer sterk deurgewerk in die 
sogenaamde kontra-revolusie wat ons dan kry en wat deur Gorbachev23 aangevoer is: "A new way of thinking is not an improvisation, nor a mental exercise. It is a result of serious reflections on the reality of today's world, of understanding that a responsible attitude to policy demands scientific substantiation, and that some of the postulates which seemed unshakable before should be given up. A biased approach, ad hoc decisions for the sake of transient goals, and departures from a strictly scientific analysis of the situation cost us dear". Daar kan gevra word of hy anders kon, of daar inderdaad ' $n$ moontlikheid was dat hy kon ingryp en die Sowjetunie behou en sodoende ook die vryheidsideaal in 'n ander rigting stuur. Die gelukkige gevolg was egter dat daar wel in baie van die lande vryheid gekom het vir mense wat jare se onderdrukking geken het. Aangrypend is die vryheid wat so onder daardie omstandighede deurbreek.

\subsection{Die kernprobleem van die Marxisme-Leninisme}

Wat moet ons dus sê, was die grootste probleem van die kommunisme? Die kommunisme in die vorm van die Marxisme-Leninisme het in die eerste plek die vryheidsideaal verkeerd verstaan. Hulle het gedink dat as hulle die mens van God sou skei, en daardie gewaande godsbeeld van hom sou wegwerp, hulle inderdaad 'n volwasse mens sou kry - 'n totaal ontwikkelde mens, 'n mondige mens - en dat daardie mondige mens en totaal ontwikkelde mens dan uiteindelik die vryheidsideaal sou kon najaag en so die ware vryheid sou kon vind. Daardie vryheid van 'n vryheidsideaal wat hy uiteindelik sou kon vind, sou daartoe lei dat hy uiteindelik sou kon bevestig dat hy vry is.

Die tweede saak wat belangrik is, is dat daar gemeen is dat die mens as arbeidende wese tot sy reg sou kom in 'n gemeenskap waar die arbeid op so 'n wyse beoefen word dat dit die mens tot opbou en tot heil sou dien. Daar is gemeen dat deur die streng beheer van die sosialisme die mens se arbeid uiteindelik so hanteer sou word dat dit sou lei tot ontwikkeling. Die teenoorgestelde het plaasgevind. Oos-Europese lande het gestagneer, terwyl Westerse lande soos Wes-Duitsland, Frankryk en Italië ekonomies gegroei het. Oos-Europese lande het geen antwoord gebied nie.

Die gedagte was weer eens edel: dat die mens daartoe gelei moes word om waarlik vry te kom. Die bedoeling was ook baie edel: deur die mens vry te maak van die situasie waarin hy verkeer het, sou hy inderdaad daarin kon slaag om waarlik vrye mens, homo liberitas, te wees. In dié verband skryf Schoeman24: "Can it be that Marx (without doubt unsuspectingly!) sensed that an important dimension of the christian Gospel never received appropriate emphasis, and that there was little prospect of 
this ever happening, he perverted, at it were, this pivotal idea of Christianity and secularized it to become the mainspring of his profane doctrine of 'new' hope for the repressed masses? Did he not also, through this profane 'gospel' of liberation and redemption, engender a secular 'proletariat' with a worldly vision of a new humanity and a new (socialist/communist) 'heaven on earth'"? Dit alles het vasgeloop teen die werklikheid.

Reimer's toon oortuigend aan dat die ideaal van Perestroika misluk het: "Perestroika presupposed the shift of power from the dominant interest group to a new cluster of socio-economic realities. And they did not do it that easily "for a better purpose'. Perestroika had to fail".

Die kerk onder hierdie omstandighede was totaal onvoorbereid vir wat gebeur het. Die kerk het eintlik geen antwoord gehad op die ineenstorting van die Marxisme-Leninisme nie en het ook geen antwoord gehad op die probleme wat daarna na vore sou kom nie. Die kerk het inderdaad verbaas gestaan oor wat plaasgevind het. En alhoewel daar pogings was om ontwikkeling te bring vanuit die kerklike hoek, het die kerk eintlik grootliks misluk in sy pogings om die nuwe vryheidsideaal wat na vore gekom het, in die regte rigting te stuur. Die nuwe vryheidsideaal is dus nie deur die kerk in 'n positiewe rigting gestuur nie. Die nuwe vryheidsideaal is nie deur die kerk ontdek en gerig nie. Reimer ${ }^{26}$ toon aan dat Gorbachev uitgereik het na die kerk in ekumeniese verband om hulle betrokke te kry by Perestroika. Die kerke kon nie reageer op die versoek nie, omdat hulle onvoorbereid was vir sosiale verantwoordelikheid. Die Christene in Rusland kon nie oorbeweeg van 'n geslote sisteem na groter betrokkenheid nie.

Die Marxisme-Leninisme het ontbondel, daar het ineenstorting gekom, daar het bittere burgeroorloë soos in Herzegovina en Kroasië en Bosnië gekom, en uiteindelik het die verrassing van die opkoms van die nuwe vryheid in Oos-Europa tot 'n tragedie gelei waar baie van die vryheid wat sou kom, maar weer vervang is deur vorme van diktature.

\section{DIE KERK EN DIE VRYHEIDSIDEAAL}

Die vryheidsideaal is egter nog lewend. En nou is die belangrike vraag hoe hierdie vryheidsideaal wat nog lewend is, gerig moet word? Op watter wyse moet die vryheidsideaal vorentoe gestuur word? Waarheen moet die vryheidsideaal lei en wat is die kerk se taak in hierdie ondersoek na die vryheidsideaal? Wat wil die kerk uiteindelik meewerk in hierdie vryheidsideaal? Waartoe wil die kerk meewerk? Die kerk in baie wye verband, ook 
in ekumeniese verband, sou in hierdie rigting moes dink om in die nabloei van die Marxisme-Leninisme ' $n$ nuwe pad aan te dui.

Sending in die allesomvattende sin van die bring van die evangelie van Jesus Christus in alle aspekte van die lewe, sal ook hieraan aandag moet gee. Die kerk sal inderdaad die rigting moet inslaan van 'n rigtinggewer binne hierdie nuwe verband.

In die eerste plek sal die kerk moet vra na die wortels van die vryheidsideaal. Die kerk sal opnuut moet probeer vasstel wat die wortel van die ideaal is en hoe hy betrokke kan raak by die vryheidsideaal. Die kerk kan nie los staan van die vryheidsideaal nie. Baie besware wat teen die bevrydingsteologie ingebring kan word, is legitiem, maar die bevryding van die mens en die vryheidsideaal wat leef in die Westerse mens is tog wesenlik. Die kerk sal daarmee moet handel. Die kerk sal sekerlik moet sê dat Jesus Christus die volledige vryheid bied en dan sal 'n mens na 2 Korintiërs 5:21 moet gaan kyk waar gesê word God het Hom as sondaar in ons plek behandel sodat ons kan word die geregtigheid van God in Hom. God bring die heil. God bring die verlossing. God bring die verheerliking alles vind plaas in diens en gehoorsaamheid aan God, maar so kan die vryheidsideaal nuwe betekenis kry. So kan die vryheidsideaal ook in die rigting gestuur word van 'n nuwe verhouding met God.

Dat die vryheidsideaal mense op 'n totaal verkeerde pad kan lei, is deur die Marxisme-Leninisme bewys. Die bevrydingsteologie moet dit ook as ernstige waarskuwing raaksien. Maar die vryheidsideaal kan ook aangewend word om mense in die rigting te stuur waar hulle die ware vryheid kan ontdek - die vryheid wat hulle kan lei tot 'n nuwe gemeenskap, 'n nuwe verhouding met God, waar hulle inderdaad in daardie nuwe verhouding met God kan leef en hom kan verheerlik. Reimer27 voer aan dat die universele kerk betrokke behoort te raak by Oos-Europa, nie in die sin van tref - en - trap - evangelisasie nie, maar in totale oorgawe aan die boodskap van Jesus Christus. Hy noem die volgende aspekte van sodanige betrokkenheid:

* Vereenselwiging van die kerk van buite met die mense in OosEuropa is noodsaaklik.

* 'n Toegewyde lewe is nodig sodat die evangelie nagevolg kan word. Christenskap moet primêr die uitgangspunt wees en dan eers ander sake soos denominasies en bevolkingsgroep.

* God moet toegelaat word om die persoon se lewe te beheer.

* Daar moet veel eerder van vennootskap sprake wees as die uitdra van persoonlike geloofsbelydenisse. 
In die tweede plek sal die kerk 'n tuiste moet bied vir die mens wat totaal ontgogel is in die moderne samelewing. Die kerk sal 'n tuiste moet bied vir mense wat in meer as een opsig ontgogel is met hierdie Westerse vryheidsideaal. Juis dit wat hulle soek, het vir hulle geen heil ingehou nie. En daarom moet die kerk rekening hou met 'n nuwe situasie waar mense hulleself afvra, wat die omstandighede is waaronder hulle verkeer en hoe hulle dit moet hanteer?

In dié verband kan verwys word na sendingpogings in Kuba. Smith ${ }^{28}$ skryf soos volg. "North American groups sometimes offer help that is not high on the Cuban priority list. Groups often bring Bibles, but Bibles are now readily available. Spanish study Bibles and other Christian literature are not. Some groups offer money to pay pastors, but Cubans request friendship and partnership. They need financial help for projects, but in the context of a sharing relationship. Visitors say, 'We will come and offer you training'. Cubans say, 'Good, but we are your equals; come and learn from us what it is like to have suffered for the name of Jesus'". Wat Rusland 29 betref is daar baie stemme wat opgaan om te waarsku teen ' $n$ simplistiese benadering in evangelisasie wat nie die komplekse Russiese samelewing in ag neem nie. Daar is reeds aangedui dat die talle korttermynuitreikings baie negatiewe gevolge gehad het.

'n Ware vryheidsideaal moet dan na vore gebring word, 'n vryheidsideaal waar die vryheid van die mens binne die raamwerke van die vryheid wat God bied, gesien word, waar God vryheid skep, waar God nuwe moontlikhede skep, waar God die kerk kan gebruik om nuwe moontlikhede te skep. Hier dink ons veral aan die gedagte wat baie sterk na vore kom in die heil in Jesus Christus wanneer Hy die verlossing teweegbring.

Die derde manier waarop die kerk betrokke kan raak in die nabloei van die Marxisme-Leninisme is om die vakuum gelaat deur die ineenstorting van die Marxisme-Leninisme wat die denke van die mens betref en die gehoorsaamheid aan God te probeer vul sodat daar inderdaad gesoek word na 'n nuwe verhouding met God en na gehoorsaamheid in Sy diens. Die kerk sal egter daarteen moet waak om as kerk die gemeenskap te beheer. Die kerk in ekumeniese verband kan nie die gemeenskap oorneem en verkerklik nie. Die kerk dien en rig die gemeenskap op God en wat Hy van die kerk verlang. Die kerk is egter nie God se koninkryk nie. In hierdie verband moet die kerk in die nabloei van die Marxisme-Leninisme met groter ywer die ware boodskap van bevryding verkondig. Die kerk is geroep om juis nou aan mense die hulp te bring wat hulle nodig het om 'n nuwe toekoms tegemoet te gaan en dan ook in die nuwe toekoms op God te bly hoop en verder invloed in die gemeenskap uit te oefen om sodoende die heil wat God skenk aan hulle te bring. 
Evangelisasieveldtogte wat egter nie die aard van byvoorbeeld die Russiese gemeenskap deeglik verken nie, lei nie tot heil nie, maar tot die uitkalwing van ware toewyding aan God. Die evangeliseringsproses sal alleen sinvol verloop as rekening daarmee gehou word dat die Westerse kerk eerder by die kerk wat onder die Marxisme-Leninisme verdruk is, kan leer. Die kerke sal na mekaar moet uitreik en in hulle uitreiking na mekaar by mekaar aansluiting moet vind.

\section{SLOT}

Ten slotte sal die kerk sy onvermoë om te getuig en te bely moet erken. Die Westerse kerk het nagelaat om die kerk in Oos-Europa te versterk en dit aan sendingorganisasies soos Geopende Deure oorgelaat. Die kerk het nie in die sentrum van belydenis, ondersteuning en hoop gestaan nie. Juis om daardie rede sal die kerk voortdurend moet vra wat daar is wat getuig en bely moet word wat nie met die tyd verander nie en wat nie met politieke omwenteling prysgegee moet word nie. Wat is die sentrale boodskap wat die kerk moet bely? Die kerk sal steeds moet bely dat die sentrale boodskap sentreer om die plaasvervanging in Jesus Christus.

\section{NOTAS:}

1 K Marx, Capital (translated by S Moore and E Aveling) London 1912.

$2 \quad$ Marx, $a w, 50$.

3 D McLellan, Karl Marx: Selected Writings, Oxford 1977, 71.

4 M Morishima, Marx's Economics. A dual theory of value and growth, Cambridge 1973, 193-196.

$5 \quad$ Marx, $a w, 423$.

6 L Kolakowski, Main currents of Marxism, 1. The Founders (translated by P S Falla), Oxford 1978, 1 ev.

$7 \quad$ Kolakowski, $a w, 413$.

8 Kolakowski, $a w, 374-375$.

9 J Seigel, Marx's fate, Princeton 1978, 391.

10 J Mepham, From the Grundriss to Capital: The making of Marx's method. In J Mepham and D-H Ruben, Issues in Marxist philosophy, Sussex 1979, 156-157.

11 P Duvenhage, Die kritiese teorie as 'n filosofiese perspektief op die twintigste eeu. Tydskrif vir Christelike Wetenskap 30/2 (1994), 38: 32-55.

12 R Kilminster, Theory and practice in Marx and Marxism. In G H R Parkinson, Marx and Marxism, Cambridge 1982, 174-175.

13 A Carter, Marx. A radical critique, Brighton, Sussex 1988, 264.

14 D McLellan, Marxism and religion, New York 1987, 30.

15 T Beeson, Discretion and valour, Glascow, 1982.

16 M Bourdeaux, Opium of the people, London 1965, $206 \mathrm{ev.}$ 
17 H Gollwitzer, Die Existenz Gottes im Bekenntnis des Glaubens, München 1964, 76-78.

$18 \mathrm{~J} \mathrm{M}$ Lochman, Encountering Marx. Bonds and barriers between Christians and Marxists, Philadelpia 1977, 117-128.

19 D Rossouw, Christen, Kommunis en Sosialis in die nuwe Suid-Afrika, 1992, Pretoria.

20 Rossouw, $a w, 92$.

21 M Gorbachev, Perestroika, New York 1987, 21-22.

22 G M Danilenko, International Law-making: Issues of law and policy, In A Carty and G Danilenko, Perestroika and International Law, New York 1990, 15.

23 Gorbachev, $a w, 131$.

24 P G Schoeman, The Christian and ideology, Tydskrif vir Christelike Wetenskap 31/3 (1995), 17:10-19.

25 J Reimer, Mission in post-perestroika Russia, Missionalia 24/1 (1969), 22:1839.

26 Reimer, $a w, 25$.

27 Reimer, $a w, 33$.

28 H Smith, Ministry to Cuba: The right questions to ask, Evangelical Missions Quarterly, 33/1 (1997), 65:60-67.

29 J Johnson, Three things you should not believe about ministry in the former Soviet Union, Evangelical Misions Quarterly 30/3 (1994), 298:294-299. 